\title{
Cold stress induces specific antioxidant responses in honey bee brood
}

\author{
Claudio Andoni Mucci, Leonor RAmirez (1), Rocío Soledad GIFFonI, \\ Lorenzo LAMATTINA \\ Instituto de Investigaciones Biológicas (IIB), Consejo Nacional de Investigaciones Científicas y Técnicas (CONICET), \\ Universidad Nacional de Mar del Plata (UNMdP), CC1245, 7600, Mar del Plata, Argentina
}

Received 21 September 2020 - Revised 13 January 2021 - Accepted 4 February 2021

\begin{abstract}
Multiple harmful factors cause chronic sub-lethal stress in managed honey bee colonies. In weak colonies, worker bees may not efficiently maintain the optimum temperature $\left(33-36^{\circ} \mathrm{C}\right)$ in peripheral brood development areas. A short period at $25^{\circ} \mathrm{C}$ induces physiological adjustments and increases the mortality in honey bee brood reared in vitro. Molecular damage due to oxidative imbalance can be one of the main causes of mortality when organisms are under stress. Here, we demonstrate that in vitro rearing honey bee brood exposed 3 days at suboptimal temperature $\left(25^{\circ} \mathrm{C}\right)$ does not lead to $\mathrm{H}_{2} \mathrm{O}_{2}$ accumulation and oxidative protein damage. Cold-stressed honey bee brood showed increased levels of both total antioxidant status (TAS) and expression of peroxiredoxins PRXI and $P R X 4$, but not of catalase activity. Results indicate that specific antioxidant defenses induced in honey bee brood under moderated cold stress are enough to keep $\mathrm{H}_{2} \mathrm{O}_{2}$ levels under control and avoid major protein damages. It is concluded that the increase of mortality in cold-stressed brood are due to multifactor's, beyond uncontrolled oxidative injuries.
\end{abstract}

\section{honey bee brood / cold stress / oxidative damage / antioxidant responses}

\section{INTRODUCTION}

Honey bee brood is extremely stenothermic, and it relies on precise regulation of rearing temperature $\left(33-36^{\circ} \mathrm{C}\right)$ for proper development (Seeley and Visscher 1985). Under cold stress, thermal regulation in the colony is accomplished by the cooperation of all colony members (Stabentheiner et al. 2010). This includes active (endothermic) heat production by honey bees on the combs and inside cells, changes of bee density within the colony, evaporative cooling with water,

Corresponding author: L. Ramirez,

lramirez@mdp.edu.ar;

L. Lamattina, lolama@mdp.edu.ar

Claudio Andoni Mucci and Leonor Ramirez contributed equally to this work.

Manuscript editor: Monique Gauthier and regulation of internal heat transport via convection (Lindauer 1955; Seeley 1983; Stabentheiner et al. 2010; Schäfer et al. 2011).

Managed honey bee colonies, wild bees, and other pollinators currently experience population losses representing a global concern (Goulson et al. 2015). Habitat loss and fragmentation of natural lands, pesticide application and environmental pollution, the spread of pathogens, and climate change represent serious threats to pollinator populations (Potts et al. 2010). Honey bees react to stressors by accelerating their behavioral development and foraging precociously (Schulz et al. 1998; Woyciechowski and Moroń 2009; Colin et al. 2019). Precocious foragers are less effective than normal-aged foragers to sustain the nutrient demand of the colony; they die soon resulting in a rapid colony population decline and inefficient conditions for brood rearing (Perry 
et al. 2015). As a result, the number of newly emerged bees decreases and, again, heating and nursing processes becomes ineffective, leading to a detrimental cycle that ends with colony collapse (Becher et al. 2009).

In a recent study, we demonstrated that a short period of sub-optimal temperature $\left(25^{\circ} \mathrm{C}\right)$ increases approximately $40 \%$ the mortality of in vitro-reared honey bee brood (Ramirez et al. 2017). Moreover, low temperature induced the expression of genes involved in the antioxidant and heat shock responses in honey bee brood (Ramirez et al. 2017). In Drosophila melanogaster adults growing at low temperatures, metabolic pathways associated to processes avoiding or repairing oxidative damages were identified via transcriptomic and metabolomic approaches (MacMillan et al. 2016). Oxidative stress results when the dynamic balance between reactive oxygen species (ROS) generation exceeds the capacity of antioxidant defenses to remove those toxic species. ROS are mostly neutralized by enzymatic and non-enzymatic detoxification mechanisms. Key components of the antioxidant enzyme system have been identified from the honey bee genome (Corona and Robinson 2006). Non-enzymatic antioxidant compounds are less specific than antioxidant enzymes; some examples are albumin, glutathione, ascorbate, tocopherol, carotenoids, among others. The whole suite of these antioxidants present in a certain biological matrix may be estimated measuring total antioxidant status (Costantini 2011).

The transcript levels of Cytochrome $C$, an electron carrier in mitochondria, increase in coldstressed honey bee brood, suggesting a raise in the metabolic rate (MR) (Ramirez et al. 2017). It was also shown that cold-stressed brood experienced high MR (Ramirez et al. 2020). Higher MR has been linked to greater ROS production and has been suggested to be a physiological cost of compensatory growth occurring after the cold stress period (De Block and Stoks 2008). Thus, keeping MR high may represent an imbalance of ROS levels and an increase of antioxidant responses in cold-stressed organisms (Lalouette et al. 2011). Herein, we challenged the hypothesis that sub-optimal rearing temperature of $25^{\circ} \mathrm{C}$ leads to cellular damage by ROS in honey bee brood. We determined brood survival, hydrogen peroxide $\left(\mathrm{H}_{2} \mathrm{O}_{2}\right)$ accumulation, protein carbonylation levels, total antioxidant status (TAS), catalase activity, and transcript level of two peroxiredoxin enzymes, during the cold stress and 1 day after returning honey bee brood to standard rearing temperature of $34^{\circ} \mathrm{C}$.

\section{MATERIALS AND METHODS}

\subsection{In vitro rearing of honey bee brood}

Larvae of Apis mellifera (A. mellifera ligustica - A. mellifera mellifera) of some hours from hatching were collected from hives belonging to "Centro de Investigación en Abejas Sociales" (CIAS) located in Santa Paula, route 226, Km 10, Mar del Plata, Argentina. Larvae were transferred to rearing plates and were incubated under standardized conditions at the laboratory: $34^{\circ} \mathrm{C}$ and $96 \%$ humidity during the larval stage (the first 6 days since larva hatching) and $34^{\circ} \mathrm{C}$ and $70 \%$ humidity during the prepupal stage (days 7 and 8 since larva hatching) (Crailsheim et al. 2013; Medrzycki et al. 2010; Ramirez et al. 2017). The amount and composition of the diet of honeybee larvae were as detailed in Ramirez et al. (2017). For the sub-optimal temperature treatment, a group of 4-day-old larvae was transferred into an incubator at $25^{\circ} \mathrm{C}$ for 3 days (cold-stressed larvae) and then returned to $34^{\circ} \mathrm{C}$ for 1 day. Figure 1 shows the experimental design used to investigate the oxidative stress in honey bee brood exposed to cold stress.

\subsection{Survival determination}

Survival was measured as the percentage of brood alive from an initial number of brood $(100 \%)$ at the start point of cold stress treatment. Dead brood was detected by both lack of mobility and growth, and their dark appearance; they were counted daily and removed from brood plates.

\subsection{Quantification of hydrogen peroxide in hemolymph}

Honey bee larvae were individually washed with $1 \times$ phosphate-buffered saline (PBS; 0.43- 


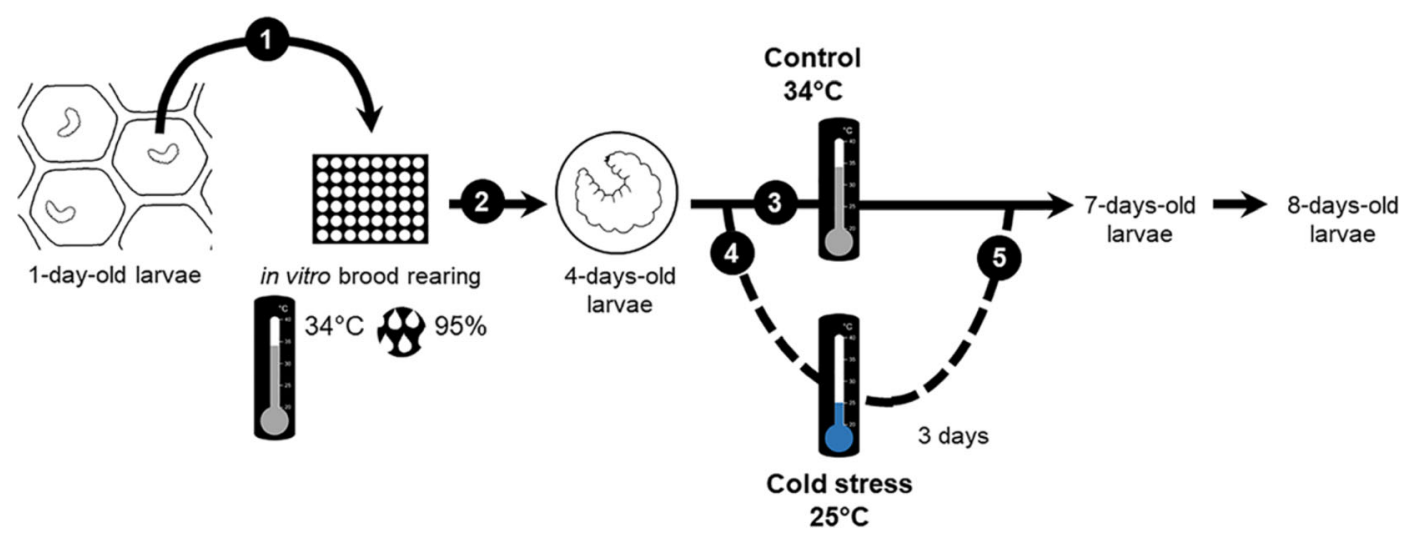

Fig 1. Experimental design used for in vitro rearing studies of honey bee brood and cold stress exposure. Brood comb with larvae less than 1-day-old was chosen from a hive and the larvae were transferred to 48-well culture plate which was placed into a desiccator and maintained at a relative humidity of $96 \%$ in a $34^{\circ} \mathrm{C}$ incubator (1). The in vitro rearing method was adjusted accordingly to Aupinel et al. (2005), Crailsheim et al. (2013), and Ramirez et al. (2017). Brood was kept in the standardized rearing conditions for 4 days (2) and then the larvae were separated into two groups, one was continuously reared at control temperature (3) and the other group was cold-stressed at $25^{\circ} \mathrm{C}$ for 3 days (4). After the cold stress, brood at $25^{\circ} \mathrm{C}$ was returned to control temperature $\left(34^{\circ} \mathrm{C}\right)$ for 1 day $(5)$.

$\mathrm{mM} \mathrm{Na} \mathrm{HPO}_{4}, 0.14-\mathrm{mM} \mathrm{KH} \mathrm{KO}_{4}, 13.7-\mathrm{mM}$ $\mathrm{NaCl}, 0.27-\mathrm{mM} \mathrm{KCl}$ ) and dried on filter paper to remove food debris. Larvae were punctured in the ventral side of the cuticle with a sterile G30 needle and hemolymph was collected using a micropipette. Then, it was transferred to a sterile tube and kept on ice until use. Accumulation of $\mathrm{H}_{2} \mathrm{O}_{2}$ was determined using a colorimetric method based on the commercial kit Bioxytech ${ }^{\circledR} \mathrm{H}_{2} \mathrm{O}_{2}-560$ (Oxis International). The working reagent for $\mathrm{H}_{2} \mathrm{O}_{2}$ detection was prepared mixing one part of reactive 1 (25-mM SO $4\left(\mathrm{NH}_{4}\right)_{2}+2.5-\mathrm{M} \mathrm{H}_{2} \mathrm{SO}_{4}$; R1) with 100 parts of reactive $2(100-\mathrm{mM}$ Sorbitol +125 $\mathrm{mM}$ Xylenol Orange in water; R2). Ten microliters of hemolymph was mixed with $90 \mu \mathrm{L}$ of working reagent $(\mathrm{R} 1+\mathrm{R} 2)$ in a 96-well plate. A control without $\mathrm{SO}_{4}\left(\mathrm{NH}_{4}\right)_{2}$ was prepared for each sample. Reactions were incubated at room temperature for $30 \mathrm{~min}$. Then, absorbance was measured in a 96-well spectrophotometer at $560 \mathrm{~nm}$ (EL $\times 800$, BioTek). $\mathrm{H}_{2} \mathrm{O}_{2}$ was quantified by interpolating the absorbance values in a standard curve made with commercial $\mathrm{H}_{2} \mathrm{O}_{2}$.

\subsection{Quantification of protein carbonylation}

Protein carbonylation was measured as a proxy for oxidative stress, following the method described by Wehr and Levine (2013). Whole body homogenates were used for each determination. Each sample was weighed, frozen in liquid nitrogen, and ground to a fine powder with a mortar and pestle. One hundred milligrams of powder was homogenized with $200 \mu \mathrm{L}$ of 100 $\mathrm{mM}$ sodium phosphate buffer $(\mathrm{pH} 7.4)$ and centrifuged at $10,000 \times g$ for $10 \mathrm{~min}$ at $4^{\circ} \mathrm{C}$. Supernatants were separated and protein concentration measured using the Bradford method (Bradford 1967). Proteins were separated into two aliquots of $500 \mu \mathrm{g}$, one aliquot was incubated in $0.5 \mathrm{~mL}$ of 10-mM 2,4-dinitrophenylhydrazine (DNPH) and $2-\mathrm{M} \mathrm{HCl}$, and the other in $0.5 \mathrm{~mL}$ of $2-\mathrm{M} \mathrm{HCl}$ only. After incubation for $30 \mathrm{~min}$ at $37^{\circ} \mathrm{C}$ in the dark at room temperature, mixing occasionally, a volume of $20 \%$ trichloroacetic acid (TCA) was added and the samples were centrifuged at $1000 \times g$ for $2 \mathrm{~min}$. The pellets were washed three times with $1 \mathrm{~mL}$ of ethanol/ethyl acetate $(1: 1)$ and centrifuged at $1000 \times g$ for $2 \mathrm{~min}$. The pellets were redissolved in $500 \mu \mathrm{L}$ of guanidine solution (6-M guanidine, 500-mM KCl, $\mathrm{pH} 2.5$ ). The carbonyl concentration in the sample was determined by reading the absorbance at $370 \mathrm{~nm}$ in a spectrophotometer (Gene-Quant 1300, GE Healthcare Life Sciences) and dividing the absorbance by the molar extinction coefficient of hydrazone 
$(22,000)$ as detailed in Wehr and Levine (2013). The results were expressed as nmol of carbonyl per mg of protein.

\subsection{Determination of total antioxidant status}

TAS is a measure of complete antioxidant status due to the presence of different types of molecules preventing the oxidation of a biological system. The whole body of honey bee larvae was used for the determination of TAS. Each sample was weighed, frozen in liquid nitrogen, and ground to a fine powder with a mortar and pestle. One hundred milligrams of powder was then extracted with $600 \mu \mathrm{L}$ of $100 \%$ ethanol and was incubated overnight at $4^{\circ} \mathrm{C}$, in dark with agitation. Resulting crude homogenates were centrifuged at $10,000 \times \mathrm{g}$ for $10 \mathrm{~min}$ at $4^{\circ} \mathrm{C}$. Subsequently, $150 \mu \mathrm{L}$ of supernatant was mixed with $2.85 \mathrm{~mL}$ of $0.004 \%$ (w/v) DPPH (1,1-diphenyl-2picryl hydrazyl) in $100 \%$ ethanol, and incubated overnight at $4{ }^{\circ} \mathrm{C}$ in dark with agitation. The blank contained all the reaction reagents except the sample. A Trolox (6-hydroxy-2, 3, 7, 8-tetramethyl chroman-2-carboxylic acid) standard curve was prepared for each assay using a range of $0-50$ $\mu \mathrm{g}$. Absorbance was read at $514 \mathrm{~nm}$ using a spectrophotometer (Gene-Quant 1300, GE Healthcare Life Sciences). The results were expressed in mg Trolox equivalents per $g$ of fresh weight.

\subsection{RNA isolation, cDNA synthesis, and transcript level quantification by real- time PCR}

Total RNA from each individual was isolated using TRIzol (Invitrogen, Thermo Fisher Scientific) according to the manufacturer's protocol. RNA concentration and purity was measured using a nanospectrophotometer (ThermoFisher), while the integrity of RNA was verified by electrophoresis on a $1 \%(\mathrm{w} / \mathrm{v})$ agarose gel. RNA was treated with DNAse I (Thermo Scientific) for $30 \mathrm{~min}$ at $37^{\circ} \mathrm{C}$ to remove any contaminating genomic DNA. Complementary DNA (cDNA) was synthesized using M-MLV Reverse Transcriptase (Invitrogen) following the manufacturer's protocol, using $1 \mu \mathrm{g}$ of total RNA. Negative controls for reverse transcription reactions were performed without adding reverse transcriptase enzyme.

Real-time PCR reactions were performed in StepOne real-time PCR machine (Applied Biosystems). Reaction mixtures consisted of 2 $\mu \mathrm{L}$ of 1:5 diluted cDNA, $1 \times$ Fast Universal SYBR Green Master Rox (Roche), $0.48 \mu \mathrm{M}$ of each primer, and RNAse free water until a final volume of $10 \mu \mathrm{L}$. PCR program consisted of an initial step at $95^{\circ} \mathrm{C}$ for $10 \mathrm{~min}$ and 40 cycles of $95^{\circ} \mathrm{C}$ for $15 \mathrm{~s}$ and $60^{\circ} \mathrm{C}$ for $1 \mathrm{~min}$. Specificity of the reaction was checked by analysis of the melting curve of the final amplified product. Primers used for quantitative real-time PCR of honeybee transcripts were designed using the Primer-BLAST tool from NCBI and are summarized in Table I. Amplification results were expressed as the starting concentrations (expressed in arbitrary fluorescence units) in RNA samples for each transcript according to the method described by Ruijter et al. (2009), employing the transcript level ratio between each target gene and the reference gene (actin related protein).

\subsection{Catalase activity}

Catalase assays were performed as previously described by Weirich et al. (2002), with minor modifications. Whole body homogenates from honeybee larvae were used for each determination. Homogenates were performed in liquid nitrogen with a mortar and pestle and $100 \mathrm{mg}$ of powder was dissolved in $200 \mu \mathrm{L}$ of $50-\mathrm{mM}$ potassium phosphate buffer ( $\mathrm{pH}$ 7.4) with $1 \mu \mathrm{L}$ of protease inhibitor cocktail (Sigma-Aldrich). The homogenates were centrifuged at $10,000 \times g$ for $10 \mathrm{~min}$ and total protein concentration was quantified in the supernatants using the Bradford method (Bradford 1967). Assay mixtures contained $40 \mu \mathrm{g}$ of total proteins and $10-\mathrm{mM} \mathrm{H}_{2} \mathrm{O}_{2}$ in a final volume of $1 \mathrm{~mL}$ completed with $50-\mathrm{mM}$ potassium phosphate buffer ( $\mathrm{pH}$ 7.4). A blank was prepared with $10-\mathrm{mM} \mathrm{H}_{2} \mathrm{O}_{2}$ in $1 \mathrm{~mL}$ of $50-\mathrm{mM}$ potassium phosphate buffer ( $\mathrm{pH}$ 7.4). The decomposition of $\mathrm{H}_{2} \mathrm{O}_{2}$ was recorded at $240 \mathrm{~nm}$ using a spectrophotometer (Gene-Quant 1300, GE Healthcare Life Sciences). The catalase activity 
Table I. Sequences of primers used for real-time RT-PCR

\begin{tabular}{|c|c|c|c|c|}
\hline Gene name & Gen ID & Forward primer (5'-3') & Reverse primer ( $\left.5^{\prime}-3^{\prime}\right)$ & Reference \\
\hline Peroxiredoxin 1 & 409954 & $\begin{array}{l}\text { CAGCATCTACTGATTCTCAC } \\
\text { TTC }\end{array}$ & $\begin{array}{l}\text { AGACCACGAAATGG } \\
\text { AACTCC }\end{array}$ & \\
\hline Peroxiredoxin 4 & 551975 & $\begin{array}{l}\text { ATCCAACATCCACTGGACGC } \\
\text { AATGT }\end{array}$ & $\begin{array}{l}\text { TTTCACCTGGCACC } \\
\text { CAGTTAGCAG }\end{array}$ & \\
\hline $\begin{array}{l}\text { Actin related } \\
\text { protein }\end{array}$ & 406122 & TGCCAACACTGTCCTTTCTG & $\begin{array}{l}\text { AGAATTGACCCACC } \\
\text { AATCCA }\end{array}$ & $\begin{array}{l}\text { (Mutti et al. } \\
\text { 2011) }\end{array}$ \\
\hline
\end{tabular}

was calculated using the molar extinction coefficient of $\mathrm{H}_{2} \mathrm{O}_{2}$ at $240 \mathrm{~nm}\left(43.6 \mathrm{M}^{-1} \mathrm{~cm}^{-1}\right)$ and was expressed as nanomoles of $\mathrm{H}_{2} \mathrm{O}_{2}$ degraded per minute per mg of total protein.

\subsection{Statistics}

All data are presented as mean \pm SE. Generalized linear mixed model (GLMM) with a binomial error structure and "logit" link function was used to model survival. Lognormal or gamma ("inverse" link function) error structures were used to model $\mathrm{H}_{2} \mathrm{O}_{2}$ accumulation, protein carbonylation, TAS, relative gene expression, and catalase activity as responses in relation to the explanatory variable (rearing temperature, 34 and $25^{\circ} \mathrm{C}$ ). ANOVA was used to test for significance of the explanatory variable in each response assessed. All statistical tests used $\alpha=0.05$ to establish significance. The "rearing temperature" was included in the model as fixed effect and "the independent experiment" was included as random effects. All analyses were performed with $\mathrm{R}$ (R Core Team 2015) using the packages lme4 and nlme.

\section{RESULTS}

\subsection{Survival, $\mathrm{H}_{2} \mathrm{O}_{2}$ accumulation, and oxidative damage to proteins in cold- stressed honey bee brood}

The survival rate of honey bee brood exposed to cold stress $\left(25^{\circ} \mathrm{C}\right)$ from day 4 to day 7 decreased progressively compared to brood reared continuously at control temperature $\left(34^{\circ} \mathrm{C}\right)$, but this was not statically significant (5-day-old: $t_{12}=1.24, P=0.2358 ; 6$-day-old: $t_{12}=1.43$, $P=0.1763$; 7 -day-old: $t_{12}=1.98, P=0.0706$;
Figure 2). When cold-stressed brood was returned to $34^{\circ} \mathrm{C}$ (8-day-old brood), the survival rate significantly decreased by approximately $20 \%$ compared to brood continuously reared at control temperature $\left(t_{12}=2.82 ; P<0.05\right.$; Figure 2$)$. Previously, we demonstrated that cold-stressed brood has a high MR (Ramirez et al. 2017), and this could lead to a greater accumulation of ROS and, consequently, be a factor causing the brood mortality. Thus, we assessed $\mathrm{H}_{2} \mathrm{O}_{2}$ accumulation and protein carbonylation levels in cold-stressed brood. No differences were found in either $\mathrm{H}_{2} \mathrm{O}_{2}$ accumulation (5-day-old: $t_{30}=-0.01, P=0.9914$; 7-day-old: $t_{38}=0.3, P=0.7616$; Figure $3 \mathrm{a}$ ) or protein carbonylation levels (5-day-old: $t_{15}=-0.8, P=0.4115$; 7day-old: $t 18=-0.9, P=0.3509$, Figure $3 b$ ) in coldstressed honey bee brood compared to brood reared continuously at $34^{\circ} \mathrm{C}$. Several samples required for the evaluation of $\mathrm{H}_{2} \mathrm{O}_{2}$ and protein carbonylation in 8-day-old honey bee brood could not be considered in the analysis because they presented contamination with fat body and other substances that interfere with such determinations

\subsection{Antioxidant responses}

To further study oxidative stress in coldstressed honey bee brood, we evaluated the induction of some antioxidant responses. We measured the levels of TAS as the ability of non-enzymatic components in the organism to prevent ROS damage (Ghiselli et al. 2001). TAS was unchanged in 5 -day-old brood exposed one day at $25^{\circ} \mathrm{C}$ $\left(t_{12}=1.1, P=0.2829\right.$; Figure 4$)$. In brood exposed for 3 day at $25^{\circ} \mathrm{C}$ (measured on day 7) and brood exposed to cold stress and transferred back to $34^{\circ} \mathrm{C}$ for 1 day (measured on day 8 ), we determined a significant increase in TAS compared to 


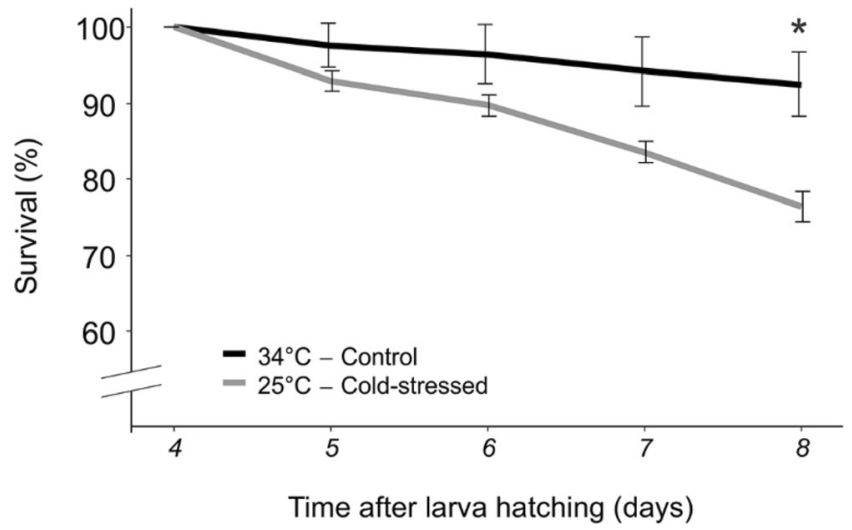

Fig 2. Survival rate of honey bee brood reared at sub-optimal temperature of $25^{\circ} \mathrm{C}$. Four-day-old honey bee larvae were reared at control temperature $\left(34^{\circ} \mathrm{C}\right.$, black line $)$ or cold-stressed $\left(25^{\circ} \mathrm{C}\right.$, grey line $)$ for 3 days, from day 4 to day 7 , and then were returned to $34^{\circ} \mathrm{C}$ for 1 day. Survival rate was expressed as a percentage of living brood in each day taking as $100 \%$ the number of individuals at the onset of the experiment (day 4). Data are shown as mean $\pm \mathrm{SE}$ of at least three independent experiments. Asterisk indicates significant differences between values at $\alpha=0.05$.

brood reared continuously at $34^{\circ} \mathrm{C}$ (7-day-old larvae: $t_{8}=-3.9, P<0.05 ; 8$-day-old brood: $t_{13}=-6.8$, $P<0.0001$; Figure 4).

The transcript levels of peroxidases $P R X 1$ and $P R X 4$ did not change in 5-day-old brood exposed at $25^{\circ} \mathrm{C}$ for 1 day compared with the brood continuously reared at $34^{\circ} \mathrm{C}\left(P R X 1: t_{23}=-1.2\right.$, $P=0.2498 ; P R X 4: t_{23}=0.7, P=0.4993$; Figure 5). Figure 5 shows that $P R X 1$ and $P R X 4$ expression increased $\simeq 3$ and $\simeq 18$ times, respectively, in brood exposed 3 days at $25^{\circ} \mathrm{C}$ compared with the control group (7-day-old brood, $P R X 1: t_{23}=-7.1$, $P<0.0001 ; P R X 4: t_{28}=-11.1, P<0.0001$; Figure 5) and these differences were maintained in 8-day-old brood ( $P R X 1: t_{25}=-11.4, P<0.0001$; $P R X 4: t_{11}=-9.3, P<0.0001$; Figure 5).

We evaluated the effect of cold stress on the catalase activity in honey bee brood. No significant differences were found on catalase activity between brood reared at control

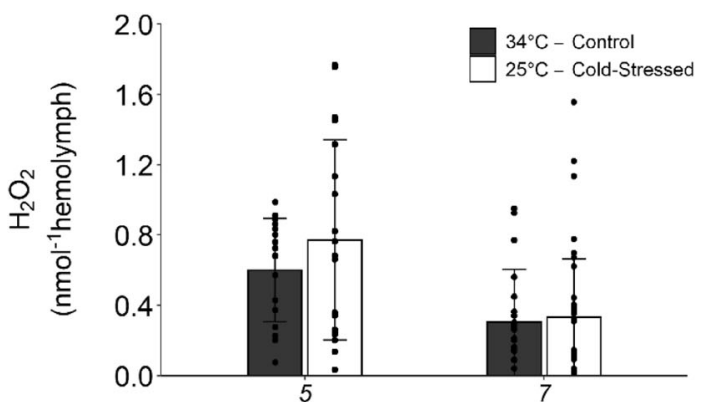

Time after larva hatching (days)

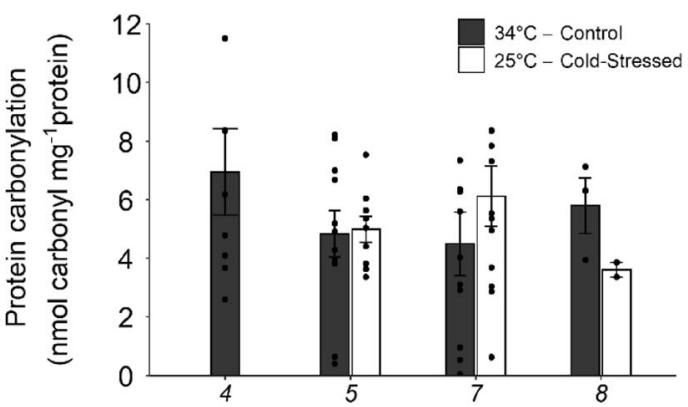

Time after larva hatching (days)

Fig 3. $\mathrm{H}_{2} \mathrm{O}_{2}$ and protein carbonylation levels in honey bee brood reared at $34^{\circ} \mathrm{C}$ and sub-optimal temperature of $25^{\circ} \mathrm{C}$. Four-day-old honey bee larvae were reared at control temperature $\left(34^{\circ} \mathrm{C}\right.$, grey bar) or cold-stressed $\left(25^{\circ} \mathrm{C}\right.$, white bar) for 3 days, from day 4 to day 7 , and then were returned to $34^{\circ} \mathrm{C}$ for 1 day. (A) $\mathrm{H}_{2} \mathrm{O}_{2}$ accumulation in hemolymph and (B) protein carbonylation in full body were measured as described in "Materials and methods." Data are shown as mean $\pm \mathrm{SE}$ of at least three independent experiments of each measurement, except for protein carbonylation at day 8 (one experiment). 


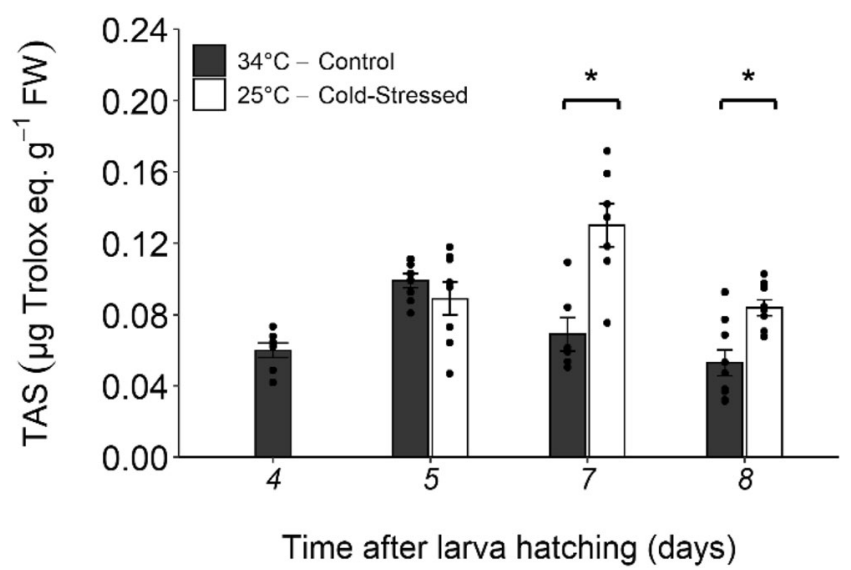

Fig 4. Total antioxidant status (TAS) in honey bee brood reared at $34^{\circ} \mathrm{C}$ and sub-optimal temperature of $25^{\circ} \mathrm{C}$. Fourday-old individuals were reared at control temperature $\left(34^{\circ} \mathrm{C}\right.$, grey bars) or cold-stressed at $25^{\circ} \mathrm{C}$ (white bars) for 3 days and then were returned to $34^{\circ} \mathrm{C}$ for 1 day. TAS was determined as described in "Materials and methods." $\mathrm{FW}$ : fresh weight. Data are shown as mean $\pm \mathrm{SE}$ of at least three independent experiments. Asterisks indicate significant differences between values at $\alpha=0.05$.

temperature and cold-stressed brood (5-dayold: $t_{14}=-0.54, P=0.5936 ; 7$-day-old: $t_{26}=-0.9, P=0.3418 ; 8$-day-old: $t_{23}=-1.5$, $P=0.1567$; Figure 6).

\section{DISCUSSION}

In several studies, oxidative stress has been linked to stressors influencing honey bee health and colony productivity. The movement of managed honey bee colonies across different agricultural landscapes and the location of colonies inside greenhouses impact on the levels of oxidative stress (Morimoto et al. 2011; Simone-Finstrom et al. 2016). Moreover, flight activity, invasive predator species, and pathogens in hives as well as pesticides used for pest control in numerous crops disturb the honey bee oxidative homeostasis (Balieira et al. 2018; Gregorc et al. 2018; Margotta et al. 2018; Leza et al. 2019; Li et al. 2020). Oxidative stress has been suggested to lead to damage in insects exposed to low temperatures (Lalouette et al. 2011; Kojić et al. 2019; Tawfik et al. 2020). Here, we studied the impact of suboptimal rearing temperature on the oxidative status and the antioxidant responses induced in honey bee brood. We report that sub-optimal rearing temperature of $25^{\circ} \mathrm{C}$ increases brood mortality from day 4 to day 8 , becoming statically significant in 8-day-old individuals exposed 3 days to cold stress and transferred back for 1 day to standard rearing temperature of $34^{\circ} \mathrm{C}$ (Figure 2). We originally had hypothesized that higher metabolic rate (MR) in cold-stressed honey bee brood (Ramirez et al. 2020) leads to increased ROS formation, and consequently results in elevated cell injury and mortality. However, contrary to expectations, we did not find differences in the levels of $\mathrm{H}_{2} \mathrm{O}_{2}$ or oxidative damage in proteins in cold-stressed brood compared to brood reared at control temperature (Figure 3). This unexpected result could be linked to the activation and the increased levels of antioxidant mechanisms in brood reared at sub-optimal temperature. Accordingly, we determined high levels of TAS in honey bee brood reared under cold stress (Figure 4), suggesting a role for non-enzymatic antioxidant compounds in neutralizing ROS. Other works have demonstrated the relevant role of TAS controlling ROS levels. For instance, in honey bees fed syrup containing ascorbic acid, the prevalence and intensity of Varroa destructor infestation were lower and this was associated with elevated levels of TAS (Farjan et al. 2014). TAS in the hemolymph of 30-day-old honey bees was greater than for 1-day-old adult bees. This increased 


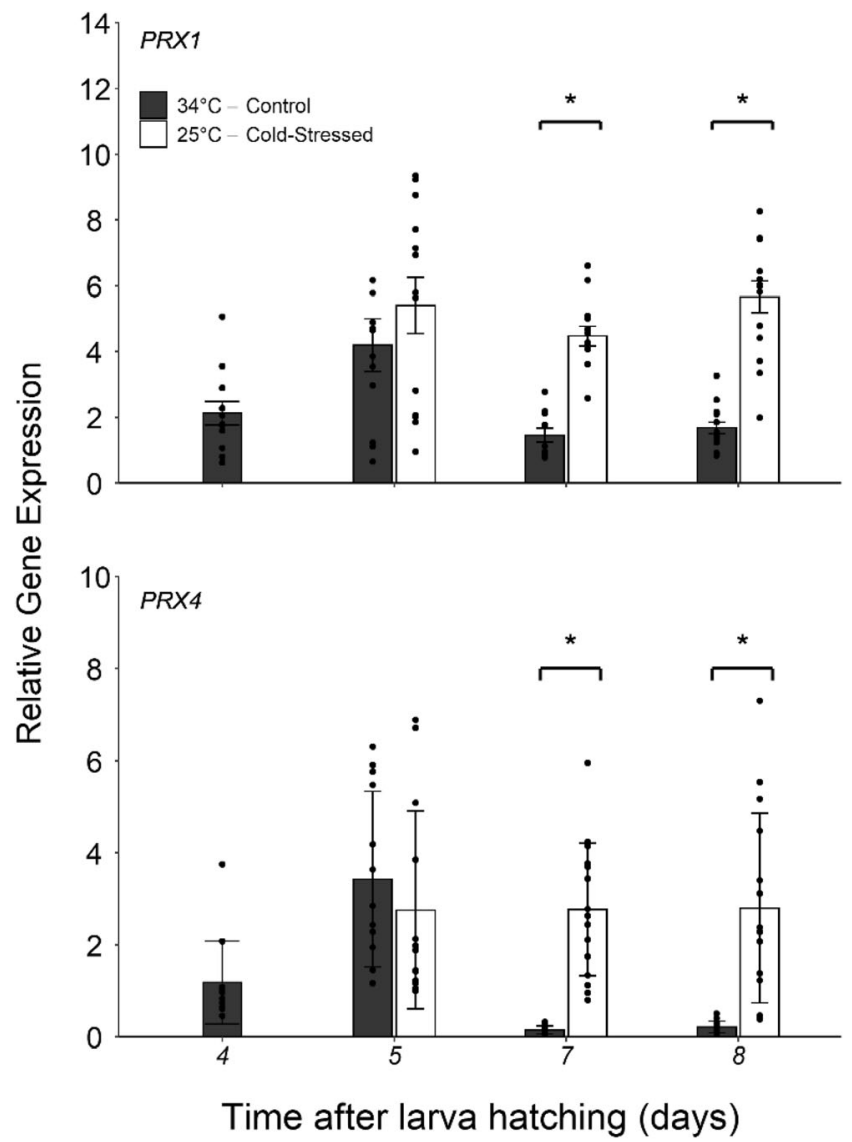

Figure 5. Peroxiredoxin 1 (PRX1) and 4 (PRX4) transcription levels measured in honey bee brood reared at $34^{\circ} \mathrm{C}$ and sub-optimal temperature of $25^{\circ} \mathrm{C}$. Four-day-old honey bee larvae were reared at control temperature $\left(34^{\circ} \mathrm{C}\right.$, grey bar) or cold-stressed $\left(25^{\circ} \mathrm{C}\right.$, white bar) for 3 days, from day 4 to day 7 , and then were returned to $34^{\circ} \mathrm{C}$ for 1 day. The relative gene expression of $P R X 1$ and $P R X 4$ was determined by RT-qPCR using actin related protein as a reference gene for normalization. Data are shown as mean $\pm \mathrm{SE}$ of at least three independent experiments. Asterisks indicate significant differences between values at $\alpha=0.05$.

protection could be associated with ageing and transition of worker bees to foraging (Słowińska et al. 2016).

ROS include a diverse variety of chemical species like superoxide $\left(\mathrm{O}_{2}{ }^{-}\right)$, hydroxyl radicals $\left(\mathrm{OH}^{-}\right)$, and $\mathrm{H}_{2} \mathrm{O}_{2}$. Previously, we reported that transcript levels of superoxide dismutase (SOD) were increased in cold-stressed honey bee brood (Ramirez et al. 2017), suggesting an increased conversion of $\mathrm{O}_{2}^{-}$to $\mathrm{H}_{2} \mathrm{O}_{2}$ and, consequently, $\mathrm{H}_{2} \mathrm{O}_{2}$ should accumulate in cold-stressed brood. However, as we described above, $\mathrm{H}_{2} \mathrm{O}_{2}$ does not accumulate in cold-stressed brood. Several antioxidant enzymes contribute to scavenge the accumulation of $\mathrm{H}_{2} \mathrm{O}_{2}$ produced by SOD, thus reducing the levels of oxidative damage to proteins, lipids, and nucleic acids (Monaghan et al. 2009). Catalase converts $\mathrm{H}_{2} \mathrm{O}_{2}$ to water and oxygen while PRXs also reduces $\mathrm{H}_{2} \mathrm{O}_{2}$ when coupled to a sulfhydryl-reducing system such as thioredoxin or glutathione (Tasaki et al. 2017). Here, we determined an increase in PRX1 and $P R X 4$ transcription levels (Figure 5) in coldstressed brood, but no changes in catalase activity were detected (Figure 6). These results suggest that PRXs are probably involved in $\mathrm{H}_{2} \mathrm{O}_{2}$ decomposition preventing its accumulation and, consequently, cell damage in honey bee brood. Termite 


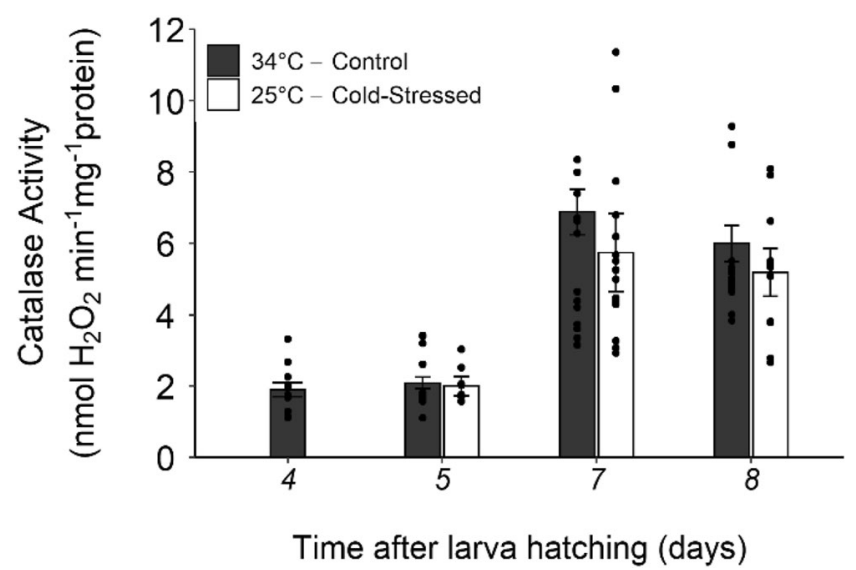

Fig 6. Catalase activity in honey bee brood reared at $34^{\circ} \mathrm{C}$ and sub-optimal temperature of $25^{\circ} \mathrm{C}$. Four-day-old honey bee larvae were reared at control temperature $\left(34^{\circ} \mathrm{C}\right.$, grey bar) or cold-stressed $\left(25^{\circ} \mathrm{C}\right.$, white bar) for 3 days, from day 4 to day 7 , and then were returned to $34^{\circ} \mathrm{C}$ for 1 day. Catalase activity was determined as described in "Materials and methods." Data are shown as mean \pm SE of at least three independent experiments.

queens have an extended lifespan and they suffer lower levels of oxidative damage than nonreproductive workers. An efficient antioxidant system consisting of several antioxidant enzymes, especially high catalase activity and PRX gene expression levels, seems to play an important role in the oxidative stress resistance of termite queen (Tasaki et al. 2017). In honey bees, brain plasticity is positively associated with the levels of cellular maintenance proteins such as Heat Shock protein 8 (HSP8) and PRX (Baker et al. 2012). Other proteins such as HSP70, HSP90 and vitellogenin, involved in oxidative stress resistance, have been linked to cold stress tolerance in honey bee brood (Ramirez et al. 2017). These proteins have been reported to be involved in the protection of cellular components, principally other proteins, from oxidative damage (Seehuus et al. 2006; King and MacRae 2015).

The results of our study do not support our hypothesis that rearing honey bee brood at suboptimal temperature leads to protein damage caused by $\mathrm{H}_{2} \mathrm{O}_{2}$ accumulation. ROS accumulation occurs when their production exceed the organism's antioxidant defense mechanism (Monaghan et al. 2009). Our results suggest that antioxidant defenses induced in cold-stressed honey bee brood are enough to keep $\mathrm{H}_{2} \mathrm{O}_{2}$ levels under control and that the increased lethality of stressed brood could be due to mutifactors.
However, we cannot ignore the oxidative damage generated by other ROS such as superoxide or hydroxyl radicals, which were not measured in this work. We did not find evidence of differential protein carbonylation, but damage to lipids and DNA could still occur that were not measured here. In situ and tissue-level measurements could also contribute to the resolution of oxidative damage as was suggested (Torson et al. 2019).

Overall, our results show that oxidative damage would not be the cause of the higher mortality determined in the cold-stressed brood. It has been proposed that a cold-induced membrane phase transition is the direct cause of cellular chill injury. Temperature-induced perturbations in the biological membrane organization have a profound impact on its structure and function, and this represents a serious challenge for the maintenance of physiological function in animals (Hazel 1995). Additionally, apoptotic mechanisms are involved in insect chill injury (Yi et al. 1976). It has been proposed that hypothermia induces injury indirectly through the resulting depolarization by inducing $\mathrm{Ca}^{2+}$ influx promoting apoptosis/necrosis (Bayley et al. 2018). The energetic cost to keep antioxidant responses elevated could be high. In insects, energy mobilization plays a very important role in stress responses (Even et al. 2012). In spite of increasing interests, the multicausality of cold mortality in honey bee reared at sub-optimal 
temperature is yet intriguing and deserves further efforts.

\section{ACKNOWLEDGEMENTS}

The authors are very grateful to Lic. Francisco Zumpano for his valuable help with statistics and Dr. Leonardo De Feudis for beekeeping support.

\section{AUTHOR CONTRIBUTIONS}

LR and LL conceived the research and designed experiments; CAM, LR, and RSG performed the experiments and analysis; CAM, LR, and LL interpreted the data and wrote the paper.

\section{FUNDING}

This work was supported by Agencia Nacional de Promoción Científica y Tecnológica (PICT-20130904 and PICT-2017-1375 to LL, PICT-20143145 to LR) and Universidad Nacional de Mar del Plata (EXA691/14 and EXA786/16 to LL).

\section{DATA AND MATERIALS AVAILABILITY}

The datasets generated during and/or analyzed during the current study are available from the corresponding author on reasonable request.

\section{CODE AVAILABILITY}

Not applicable.

\section{DECLARATIONS}

Ethics approval Not applicable.

Competing interests The authors declare no competing interests.

Le stress dû au froid induit des réponses antioxydantes spécifiques dans le couvain d'abeilles.

Couvain d'abeilles domestiques / stress dû au froid / stress oxydatif / dommages oxydatifs / réponses antioxydantes.
Kältestress induziert die Antwort spezifischer Antioxidantien in der Brut der Honigbiene.

Honigbienenbrut / Kältestress / oxidativer Stress / oxidative Schäden / Antioxidanzantwort.

\section{REFERENCES}

Aupinel P, Fortini D, Dufour H, Tasei JN, Michaud B, Odoux JF, Pham-Delegue MH (2005) Improvement of artificial feeding in a standard in vitro method for rearing Apis mellifera larvae. Bull. Insectology 58:107-111

Baker N, Wolschin F, Amdam G V (2012) Age-related learning deficits can be reversible in honeybees Apis mellifera. Exp. Gerontol. 47:764-772. https://doi. org/10.1016/j.exger.2012.05.011.

Balieira KVB, Mazzo M, Bizerra PFV, Guimarães AR de JS, Nicodemo D, Mingatto FE (2018) Imidaclopridinduced oxidative stress in honey bees and the antioxidant action of caffeine. Int. J. Parasitol. 49:562-572. https://doi.org/10.1007/s13592-018-0583-1.

Bayley JS, Winther CB, Andersen MK, et al. (2018) Cold exposure causes cell death by depolarizationmediated $\mathrm{Ca} 2+$ overload in a chill-susceptible insect. Proc. Natl. Acad. Sci. U. S. A. 115:E9737-E9744. https://doi. org/10.1073/pnas.1813532115.

Becher MA, Scharpenberg H, Moritz RFA (2009) Pupal developmental temperature and behavioral specialization of honeybee workers (Apis mellifera L.). J. Comp. Physiol. A Neuroethol. Sensory, Neural, Behav. Physiol. 195:673-679. https://doi.org/10.1007/s00359-0090442-7.

Bradford MM (1967) A Rapid and Sensitive Method for the Quantitation of Microgram Quantities of Protein Utilizing the Principle of Protein-Dye Binding. Crop J. 5:407-415. https://doi.org/10.1016/j.cj.2017.04.003.

Colin T, Meikle WG, Wu X, Barron AB (2019) Traces of a neonicotinoid induce precocious foraging and reduce foraging performance in honey bees. Environ. Sci. Technol. 53:8252-8261. https://doi.org/10.1021/acs. est.9b02452.

Corona M, Robinson GE (2006) Genes of the antioxidant system of the honey bee: Annotation and phylogeny. Insect Mol. Biol. 15:687-701. https://doi.org/10.1111 /j.1365-2583.2006.00695.x.

Costantini D (2011) On the measurement of circulating antioxidant capacity and the nightmare of uric acid. Methods Ecol. Evol. 2:321-325. https://doi. org/10.1111/j.2041-210X.2010.00080.x.

Crailsheim K, Brodschneider R, Aupinel P, et al. (2013) Standard methods for artificial rearing of Apis mellifera larvae . J. Apic. Res. 52:1-16. https://doi. org/10.3896/ibra.1.52.1.05. 
De Block M, Stoks R (2008) Compensatory growth and oxidative stress in a damselfly. Proc. R. Soc. B Biol. Sci. 275:781-785. https://doi.org/10.1098 /rspb.2007.1515.

Even N, Devaud JM, Barron AB (2012) General stress responses in the honey bee. Insects 3:1271-1298. https://doi.org/10.3390/insects3041271.

Farjan M, Łopieńska-Biernat E, Lipiński Z, Dmitryjuk M, ZóŁtowska K (2014) Supplementing with vitamin C the diet of honeybees (Apis mellifera carnica) parasitized with Varroa destructor: Effects on antioxidative status. Parasitology 141:770-776. https://doi. org/10.1017/S0031182013002126.

Ghiselli, A., Serafini, M., Natella, F., Scaccini, C. (2001) Total Antioxidant Capacity As a Tool To Assess Redox Status: Critical View and Experimental Data. Elsevier B.V.

Goulson D, Nicholls E, Botías C, Rotheray EL (2015) Bee declines driven by combined Stress from parasites, pesticides, and lack of flowers. Science (80-. ). $347 ; 1255957$. https://doi.org/10.1126 /science. 1255957 .

Gregorc A, Alburaki M, Rinderer N, et al. (2018) Effects of coumaphos and imidacloprid on honey bee (Hymenoptera: Apidae) lifespan and antioxidant gene regulations in laboratory experiments. Sci. Rep. 8:1-13. https://doi.org/10.1038/s41598-018-33348-4.

Hazel JR (1995) Thermal adaptation in biological membranes: Is homeoviscous adaptation the explanation? Annu. Rev. Physiol. 57:19-42. https://doi.org/10.1146 /annurev.ph.57.030195.000315.

King AM, MacRae TH (2015) Insect Heat Shock Proteins During Stress and Diapause. Annu. Rev. Entomol. 60:59-75. https://doi.org/10.1146/annurev-ento011613-162107.

Kojić DK, Purać JS, Nikolić T V., et al. (2019) Oxidative stress and the activity of antioxidative defense enzymes in overwintering honey bees. Entomol. Gen. 39:33-44. https://doi.org/10.1127/entomologia/2019 /0743.

Lalouette L, Williams CM, Hervant F, Sinclair BJ, Renault D (2011) Metabolic rate and oxidative stress in insects exposed to low temperature thermal fluctuations. Comp. Biochem. Physiol. - A Mol. Integr. Physiol. 158:229-234. https://doi.org/10.1016/j. cbpa.2010.11.007.

Leza M, Herrera C, Marques A, Roca P, Sastre-Serra J, Pons DG (2019) The impact of the invasive species Vespa velutina on honeybees: A new approach based on oxidative stress. Sci. Total Environ. 689:709-715. https://doi.org/10.1016/j.scitotenv.2019.06.511.

Li Z, Hou M, Qiu Y, Zhao B, Nie H, Su S (2020) Changes in antioxidant enzymes activity and metabolomic profiles in the guts of honey bee (Apis mellifera) larvae infected with ascosphaera apis. Insects 11:1-12. https://doi.org/10.3390/insects11070419.

Lindauer M (1955) The Water Economy and Temperature Regulation of the Honeybee Colony. Bee World 36:81-92. https://doi.org/10.1080/0005772 x.1955.11094876.
MacMillan HA, Knee JM, Dennis AB, et al. (2016) Cold acclimation wholly reorganizes the Drosophila melanogaster transcriptome and metabolome. Sci. Rep. 6:1-14. https://doi.org/10.1038/srep28999.

Margotta JW, Roberts SP, Elekonich MM (2018) Effects of flight activity and age on oxidative damage in the honey bee, Apis mellifera. J. Exp. Biol. 221;jeb183228. https://doi.org/10.1242/jeb.183228.

Medrzycki P, Sgolastra F, Bortolotti L, et al. (2010) Influence of brood rearing temperature on honey bee development and susceptibility to poisoning by pesticides. J. Apic. Res. 49:52-59. https://doi.org/10.3896 /IBRA.1.49.1.07.

Monaghan P, Metcalfe NB, Torres R (2009) Oxidative stress as a mediator of life history trade-offs: Mechanisms, measurements and interpretation. Ecol. Lett. 12:75-92. https://doi.org/10.1111/j.14610248.2008.01258.x.

Morimoto T, Kojima Y, Toki T, et al. (2011) The habitat disruption induces immune-suppression and oxidative stress in honey bees. Ecol. Evol. 1:201-217. https://doi.org/10.1002/ece3.21.

Mutti NS, Wang Y, Kaftanoglu O, Amdam G V. (2011) Honey bee PTEN - description, developmental knockdown, and tissue-specific expression of splice-variants correlated with alternative social phenotypes. PLoS One 6:1-11. https://doi.org/10.1371/journal. pone.0022195.

Perry CJ, Søvik E, Myerscough MR, Barron AB (2015) Rapid behavioral maturation accelerates failure of stressed honey bee colonies. Proc. Natl. Acad. Sci. U. S. A. 112:3427-3432. https://doi.org/10.1073 /pnas.1422089112.

Potts SG, Biesmeijer JC, Kremen C, Neumann P, Schweiger O, Kunin WE (2010) Global pollinator declines: Trends, impacts and drivers. Trends Ecol. Evol. 25:345-353. https://doi.org/10.1016/j. tree.2010.01.007.

R Core Team (2015) R Core Team 2014 R: A language and environment for statistical computing. $\mathrm{R}$ foundation for statistical computing. https://www.R-project.org/. $: 2015$.

Ramirez L, Negri P, Sturla L, et al. (2017) Abscisic acid enhances cold tolerance in honeybee larvae. Proc. R. Soc. B Biol. Sci. 284:20162140. https://doi. org/10.1098/rspb.2016.2140.

Ramirez L, Luna F, Mucci CA, Lamattina L (2020) Fast weight recovery, metabolic rate adjustment and geneexpression regulation define responses of cold-stressed honey bee brood. J. Insect Physiol. 128:104178. https://doi.org/10.1101/2020.06.15.152389.

Ruijter JM, Ramakers C, Hoogaars WMH, et al. (2009) Amplification efficiency: Linking baseline and bias in the analysis of quantitative PCR data. Nucleic Acids Res. 37:e45. https://doi.org/10.1016/0003-2697(76 )90527-3.

Schäfer MO, Ritter W, Pettis JS, Neumann P (2011) Concurrent Parasitism Alters Thermoregulation in Honey Bee (Hymenoptera: Apidae) Winter Clusters. Ann. 
Entomol. Soc. Am. 104:476-482. https://doi. org/10.1603/AN10142.

Schulz DJ, Huang ZY, Robinson GE (1998) Effects of colony food shortage on behavioral development in honey bees. Behav. Ecol. Sociobiol. 42:295-303. https://doi.org/10.1007/s002650050442.

Seehuus S-C, Norberg K, Gimsa U, Krekling T, Amdam G V. (2006) Reproductive protein protects functionally sterile honey bee workers from oxidative stress. Proc. Natl. Acad. Sci. 103:962-967. https://doi.org/10.1073 /pnas.0502681103.

Seeley TD (1983) Division of labor between scouts and recruits in honeybee foraging. Behav. Ecol. Sociobiol. 12:253-259. https://doi.org/10.1007/BF00290778.

Seeley TD, Visscher PK (1985) Survival of honeybees in cold climates: the critical timing of colony growth and reproduction. Ecol. Entomol. 10:81-88. https://doi. org/10.1111/j.1365-2311.1985.tb00537.x.

Simone-Finstrom M, Li-Byarlay H, Huang MH, Strand MK, Rueppell O, Tarpy DR (2016) Migratory management and environmental conditions affect lifespan and oxidative stress in honey bees. Sci. Rep. 6:1-10. https://doi.org/10.1038/srep32023.

Słowińska M, Nynca J, Wilde J, Bąk B, Siuda M, Ciereszko A (2016) Total antioxidant capacity of honeybee haemolymph in relation to age and exposure to pesticide, and comparison to antioxidant capacity of seminal plasma. Apidologie 47:227-236. https://doi. org/10.1007/s13592-015-0391-9.

Stabentheiner A, Kovac H, Brodschneider R (2010) Honeybee colony thermoregulation - Regulatory mechanisms and contribution of individuals in dependence on age, location and thermal stress. PLoS One 5:e8967 https://doi.org/10.1371/journal.pone.0008967.
Tasaki E, Kobayashi K, Matsuura K, Iuchi Y (2017) An efficient antioxidant system in a longlived termite queen. PLoS One 12:1-16. https://doi.org/10.1371 /journal.pone.0167412.

Tawfik AI, Ahmed ZH, Abdel-Rahman MF, Moustafa AM (2020) Influence of winter feeding on colony development and the antioxidant system of the honey bee, Apis mellifera. J. Apic. Res. 1-12. https://doi.org/10.1080 /00218839.2020.1752456.

Torson AS, Yocum GD, Rinehart JP, Nash SA, Bowsher JH (2019) Fluctuating thermal regimes prevent chill injury but do not change patterns of oxidative stress in the alfalfa leafcutting bee, Megachile rotundata, J. Insect Physiol. 118:103935. https://doi.org/10.1016/j. jinsphys.2019.103935.

Wehr NB, Levine RL (2013) Quantification of Protein Carbonylation. Cell Senescence Methods Protoc. Methods Mol. Biol. 965:473-484. https://doi. org/10.1007/978-1-62703-239-1_18.

Weirich GF, Collins AM, Williams VP (2002) Antioxidant enzymes in the honey bee, Apis mellifera. 38:67-76. https://doi.org/10.1051/apido.

Woyciechowski M, Moroń D (2009) Life expectancy and onset of foraging in the honeybee (apis mellifera). Insect. Soc. 56:193-201. https://doi.org/10.1007 /s00040-009-0012-6.

Yi SX, Moore CW, Lee RE (1976) Rapid cold-hardening protects Drosophila melanogaster from cold-induced apoptosis. Anal. Biochem. 72:248-254. https://doi. org/10.1007/s10495-006-0048-2.

Publisher's note Springer Nature remains neutral with regard to jurisdictional claims in published maps and institutional affiliations. 